\title{
THE DUTCH STRATEGIC AND OPERATIONAL APPROACH IN THE INDONESIAN WAR OF INDEPENDENCE, 1945- 1949
}

\author{
Leopold Scholtz ${ }^{1}$ \\ North-West University
}

\begin{abstract}
The Indonesian War of Independence (1945-1949) and the Dutch attempt to combat the insurgency campaign by the Indonesian nationalists provides an excellent case study of how not to conduct a counter-insurgency war. In this article, it is reasoned that the Dutch security strategic objective - a smokescreen of autonomy while keeping hold of political power - was unrealistic. Their military strategic approach was very deficient. They approached the war with a conventional war mindset, thinking that if they could merely reoccupy the whole archipelago and take the nationalist leaders prisoner, that it would guarantee victory. They also mistreated the indigenous population badly, including several mass murders and other war crimes, and ensured that the population turned against them. There was little coordination between the civilian and military authorities. Two conventional mobile operations, while conducted professionally, actually enlarged the territory to be pacified and weakened the Dutch hold on the country. By early 1949, it was clear that the Dutch had lost the war, mainly because the Dutch made a series of crucial mistakes, such as not attempting to win the hearts and minds of the local population. In addition, the implacable opposition by the United States made their war effort futile.
\end{abstract}

Keywords: Indonesian War of Independence, Netherlands, insurgency, counterinsurgency, police actions, strategy, operations, tactics, Dutch army

\section{Introduction}

Analyses of counter-insurgency operations mostly concentrate on the wellknown conflicts - the French and Americans in Vietnam, the British in Malaya and Kenya, the French in Algeria, the Portuguese in Angola and Mozambique, the Ian Smith government in Rhodesia, the South Africans in Namibia, et cetera. One such war, which is almost totally unknown in South Africa, is the Indonesian War of Independence (1945-1949), in which the Dutch tried to hold on to their colony in the years immediately after the Second World War. Until relatively recently, the war - and especially the often harsh way in which the Dutch military waged it was largely buried in the country's collective consciousness. Only in recent years, 
this dark chapter in the country's history was uncovered by a series of academic publications and news reports. This elicited a more or less half-hearted public attempt at confronting the crimes of a previous generation, which included mass murders of civilians. $^{2}$ (Of course, the war crimes were not one-sided, as the Indonesian fighters were at least as guilty as the Dutch.)

On one level it is notable that a nation that had just emerged from a five-yearlong brutal Nazi occupation (1940-1945), which included severe repression and war crimes, would almost immediately proceed to visit the same kind of extreme violence on other people with a force of, according to one historian, up to 140000 soldiers at its peak in December 1948. ${ }^{3}$ Historian Peter Romijn's comment illustrates the dilemma, "[a]s it happened, the men aspired to go as liberators, arrived as unwelcome occupiers, and returned as veterans of a military adventure which had led to war crimes." $\mathrm{A}$ somewhat bewildered Dutch journalist, Ad van Liempt, asks, "[w]hat was going on with the Netherlands?" His enigmatic answer is, "[t]he more you know about it, the less of it you understand." 5

The main question addressed in the study on which this article is based, was: Why did the Dutch in the end lose the war? And what does that say about the way they waged the war? It is worth the effort to subject the way in which the Dutch attempted to put down the Indonesian nationalist uprising to a professional military analysis. It will be seen that they made fundamental strategic mistakes, just like the French, Americans and Portuguese, and that these contributed to the ultimate defeat of the latter three nations.

Why would a study like this be relevant for a South African audience? Up to 1994, counter-insurgency was a field in which the old South African Defence Force (SANDF) was well versed. In 1969, Lieutenant General CA Fraser started a long tradition of theoretical studies, ${ }^{6}$ which were put into practice in the war against SWAPO in the north of South West Africa (now Namibia) and the ANC in South Africa. ${ }^{7}$

After 1994, the SANDF expertise regarding counter-insurgency went downhill to the extent that the then chief of the army, Lieutenant General Solly Shoke, found it necessary to commission a book with several theoretical chapters and case studies about the matter. ${ }^{8}$ Still, judging by the paucity of recent theoretical counter-insurgency publications in South Africa, this book appears to be an exception. This is a pity, as one of the most important international military contributions the SANDF has made in the $21^{\text {st }}$ century, has been in the field of peace support operations. Counter-insurgency warfare often has so much in common with peace support operations that the latter cannot be pursued properly without a thorough understanding of the former. In this context, it may be worthwhile for South African military officers and theoreticians to take note of the Indonesian War of Independence and especially the flawed way the Dutch approached it. The lessons identified there will undoubtedly be of value to the SANDF as well. Every case study, whether it is about the Germans' failed counterinsurgency campaign in the Balkans in the Second World War, or the American wars 
in Iraq and Afghanistan, may contribute something to an overall mosaic to help one understand what the underlying factors of success or failure are.

This article is based on secondary sources. The main focus was not so much to uncover new facts, but rather to interpret the war according to modern insights about counter-insurgency warfare.

A final introductory remark: all quotations in the original Dutch were translated into English.

\section{Historical background}

The Dutch started colonising what was to become the Dutch East Indies early in the $17^{\text {th }}$ century. It started on the island of Java, but by the $20^{\text {th }}$ century, the Dutch had also subjected Sumatra, Bali, Celebes (now known as Sulawesi), New Guinea, a part of Borneo and other islands. This was done through several large-scale and smaller campaigns in which native resistance was put down mercilessly. The archipelago was finally subjected after the end of the Aceh campaign on Sumatra in 1903, in which about 35000 inhabitants were killed. ${ }^{9}$ Dutch military historian Jaap de Moor describes the way in which the population of Aceh was conquered (this, as we will see, had a direct bearing on the War of Independence):

Arbitrary violence, the killing of women and children, burning of kampongs [native villages] and other deeds of excessive violence dominated the vicinity of battle. The military approach stayed dominant. The claims occasionally made by [General JB] van Heutz [Dutch commander in Aceh] about 'controlled' violence and 'hitting only the war party' were progressively unmasked. Scandals came to the fore. But the war was being won; that counted. Aceh was pacified. ${ }^{10}$

During the 1930s, several Indonesian nationalist leaders were arrested and locked up. This gave rise to the illusion among the Dutch colonial administrators that the problem was solved. ${ }^{11}$ It was, of course, not.

After the start of the Second World War in Asia - in February and March 1942 until the end of the war - the islands were invaded and occupied by the victorious Japanese forces. A militarily senseless naval battle - the Battle of the Java Sea - was fought against the Japanese invaders because the naval commander in the Dutch East Indies, Vice Admiral Conrad Helfrich, feared that not to fight meant that the Dutch would lose the moral right to rule the archipelago. ${ }^{12}$

The ignominious defeat of the colonial Dutch navy and army at the hands of a non-European power did much to diminish the colonials' prestige in the eyes of the Indonesians. Having examined the Japanese occupation of Indonesia during the war, Anne Doedens and Lieke Mulder conclude: 
The Netherlands in Southeast Asia became apparent as a giant on clay feet, possessing big oil interests; indeed, the third colonial power in Asia, but in no way equipped with military forces equal to its important political and economic position in the region. ${ }^{13}$

During the war, the Japanese appointed many Indonesian natives to senior administrative positions to which they could never aspire under Dutch colonial rule. This gave the more educated Indonesians a taste of freedom from the typical apartheidlike colonial social, economic and political conditions imposed on them by the Dutch. As Swiss-Dutch historian Rémy Limpach writes, "[t]he 'European' ... upper layer was violently yanked by Japan from its colonial idyll and in 1945 no longer welcomed by the Indonesians. The defeat against Japan had invalidated the myth of Dutch supremacy."14 The Dutch, therefore, believed that the restoration of their prestige could only be achieved by a great display of power. ${ }^{15}$ This, in part, explains the excessive violence perpetrated against the locals.

The Japanese capitulation resulted in a power vacuum, as the Dutch were in no position to reclaim their colony at once. The consequence was that a group of Indonesian nationalists under the leadership of Sukarno (he, like many Javanese, had no first name) and Mohammed Hatta immediately proclaimed the independent Republic of Indonesia. They also formed their own military force, the Tentara Nasional Indonesia (TNI), which was, however, little more than a disorganised rabble at that stage. (At its peak, the TNI had about 175000 men, with a similar number of autonomous irregulars and armed gangs. ${ }^{16}$ ) A period of confusion followed in which the 250000 Japanese military stepped aside and allowed the nationalists to occupy almost the entire country. The nationalists also took possession of a substantial Japanese arsenal, including small arms, light tanks, artillery and even some 20 dilapidated aircraft. ${ }^{17}$ The first Westerners to arrive in any numbers were the British (albeit only in October 1945), who did not have sufficient troops to occupy the country effectively. Clashes with the Indonesian nationalists soon broke out. ${ }^{18}$

To make matters worse for the Dutch, the nationalist bitterness exploded in a burst of extreme violence in which approximately 25 000-30000 Dutch people, mostly still in Japanese internment camps, as well as moderate pro-Dutch Indonesians and many more members of other ethnic minorities, were ruthlessly slaughtered. This constituted about $10 \%$ of the Dutch and Eurasian population and became known as the 'Bersiap' (Malay for "to be prepared") period. ${ }^{19}$ The violence accelerated the import of Dutch military units in order to restore law and order - and, of course, to reclaim the archipelago for the Netherlands. $^{20}$

Nevertheless, when the first Dutch forces arrived in March 1946, they were only able to occupy five relatively small bridgeheads surrounding the capital, Batavia, in the west of Java, and the harbour city of Surabaya on the east end of the island. The rest of the country was firmly in nationalist hands. There things stagnated for a while during which the British and Japanese soldiers were withdrawn, although several clashes set the scene for a bitter struggle. ${ }^{21}$ 


\section{The Dutch strategic objectives}

The original Dutch motive for colonising the East Indies had to do primarily with economic factors and national prestige. Possessing a rich colony in Asia brought about great riches in the Dutch motherland while it also gave the country a certain international standing, which it would otherwise not have had. According to the Leiden historian Jan Bank, the Dutch colonial interests may be summarised in three words: rubber, religie, rijk (rubber, religion, empire). ${ }^{22}$ This was one of the reasons why a slogan was coined in the immediate post-war Netherlands - Indië verloren, rampspoed geboren (If the [Dutch] Indies is lost, catastrophe is born).

Through the latter part of the $19^{\text {th }}$ century, the economic and prestige motive was augmented by an ethical motive. According to many Dutch at the time, it was the task of the magnanimous, developed Netherlands to bring civilisation to the simple, backward Indonesians. Jos de Beus describes the Dutch ethical considerations:

Initially it was thought that it was God's reasonable will that the Netherlands conquered the East and West [Indies], that the Netherlands managed the peoples living there and developed them on Dutch terms, that the Netherlands would determine the duration of the emancipation. God did not gamble, God also did not decolonise. This was the attitude with which [Indonesian] nationalists were approached by Dutch politicians and their followers. ${ }^{23}$

In the immediate period after the Second World War (WWII), the Dutch - from their own perspective understandably - also viewed the 'rebellion' through the prism of their own WWII experience. The Indonesian nationalists, who had worked with the Japanese occupiers in 1942-1945, were seen as collaborators who were at least as bad as the Dutch Nazis who aided the German occupiers in the motherland. ${ }^{24}$ They had little or no understanding of the motives and considerations, which drove the Indonesian nationalists to refuse to countenance a resumption of Dutch colonialism.

As the Dutch military commander in the theatre, Lieutenant General Simon Spoor, told his troops in a general order:

You do not advance to bring war to this country, but to restore peace. You do not come as conqueror, but as liberator. You do not come to punish, but to protect. ... Show that you realise what it is to fight for justice and security. The Fatherland and the whole world are watching you. May God lead you and protect you while fulfilling your task $!^{25}$

Even during the war, in December 1942, Queen Wilhelmina (with the concurrence of the then government in exile) spoke in a speech of a future "imperial connection in which the Netherlands, Indonesia, Surinam and Curaçao [the last two in the Dutch West Indies] together will form part, while they each will take care of their own 
internal affairs in autonomy". This was the result of heavy pressure by the American government, who did not care to see the restoration of European colonialism in Asia. ${ }^{26}$ This fact, as we shall see, would have a direct bearing on the Indonesian conflict.

By the time the first Dutch troops arrived in Java in 1946, the situation had evolved much further. America was against the continuation of the Dutch colonialism, as were the vast majority of the Indonesians themselves. And the Republican forces, disorganised and badly trained as they mostly were, were in possession of by far the greater part of the country. ${ }^{27}$ The Dutch strategic objectives, as formulated in The Hague in 1945-1946, therefore, testify to a fundamental inability to read the post-war political climate internationally as well as in Indonesia itself.

As the Republicans - the Indonesian nationalists, in other words - were in possession of the greater part of the country, and because possession is nine tenths of the law, the Dutch were at first forced to start negotiations. However, they were not about to relinquish control. Their opening move in the chess game, as formulated by Governor-General Hubertus van Mook, was that Indonesia would form a self-ruling federation under Dutch sovereignty, and that the Republican-occupied territory would be one of several constituent states. ${ }^{28}$ Historian J Hoffenaar calls it a "divide and rule policy". ${ }^{29}$ What it really entailed, was explained in stark terms by the minister of overseas territories, Jan Jonkman, to his officials:

Our task should not be to help too much, but primarily to maintain our task overseas fully. Of this we must be fully aware before anything else is done, and this is the primary challenge of the Netherlands state: maintenance of our task overseas. The Netherlands always has been, until before this war, and must stay, a world empire..$^{30}$

Exactly how far many influential Dutch were removed from reality, may be seen in a statement made by General Spoor, in a private conversation with Lieutenant General MRH Clameyer, Chief of Staff of the Dutch Defence Force, late in 1945, namely that $97 \%$ of the Indonesian resistance could be ascribed to the influence of the Japanese, and $3 \%$ to Indonesian nationalism with a communist element. Therefore, Spoor said the Republic was "a Japanese product". The goal should thus be to neutralise the "extremists" militarily and then to negotiate with the moderates. ${ }^{31}$ The initial expectation was that this would not entail much effort. As Major-General Nico van Straten, Chief of Staff of the remains of the old colonial army, the KNIL (Koninklijk Nederlands-Indisch Leger or Royal Dutch Indies Army), wrote in September 1945, "the whole Republican movement does not mean much ... With a certain show of force the matter will collapse like a house of cards, provided that some leaders could be isolated." (However, it must be said that the Dutch army commander in West Java, Major General Wybrandus Schilling, advised his superiors that it would take five divisions five to ten years to restore Dutch rule in Indonesia. This, he perceptively said, would overburden the Netherlands. ${ }^{32}$ 
The political stalemate lasted until November 1946, when the Dutch and Republican delegations met in the mountain village of Linggajati on Java. After five days, an accord was reached. The nationalist Republic of Indonesia was recognised, but as part of a United States of Indonesia, which would comprise three member states: the nationalist Republic, Borneo and a state called De Grote Oost (the Large East), comprising the rest of the archipelago. This federation would then also be a constituent part of the Kingdom of the Netherlands, together with Surinam, the Dutch West Indies and the mother country in Europe. Through this construction, the Dutch hoped to continue their sovereignty over Indonesia and the rest of its empire. ${ }^{33}$ This was the basic strategic objective of the government in The Hague with which the greater part of the war was waged.

The accord actually had very few real supporters in both camps. The Dutch went along because they were not (yet) militarily able to defeat the nationalists; the nationalists because they saw the large Dutch military buildup, and wanted time to prepare for the inevitable explosion. It was a question of expediency. ${ }^{34}$

\section{The tension escalates}

The first Indonesian islands to be reclaimed by the Dutch military were Borneo, Celebes and Bali. There the first military operations took place, albeit in the absence of severe resistance.

As the Dutch poured troops and materiel into the main islands of Java and Sumatra in the second half of 1946, clashes between them and the nationalists escalated to the point of a fully-fledged insurgency in the Dutch-occupied territories. By November, when the British finally left, the Dutch had about 93000 uniformed soldiers there, including army, air force and navy members. (In total, about 200000 Dutch soldiers served in the East Indies in the years 1946-1950. ${ }^{35}$ ) Their forces comprised the first conscripts to be trained after the war, volunteers and the remnants of the old colonial KNIL. The 'teeth' were organised in three army divisions and a marine brigade (the latter regarded as an elite formation, trained and equipped in America) on Java, and another composite division on Sumatra. ${ }^{36}$

On the other side, the Republicans organised their force in ten 'divisions' (just under $200000 \mathrm{men})$. These, however, bore little resemblance to what a division (15 000 men or so) would comprise in a Western army. The fighters were mostly badly trained, badly equipped and badly organised. They might have been seen as a militia more than anything else. ${ }^{37}$

The Accord of Linggajati also comprised a ceasefire, but neither side ever really was committed to it, and it was violated almost daily by mutual provocations. There were considerable divisions among the nationalists, as some viewed the accord as short of the total independence they wanted..$^{38}$ On the Dutch side, there was a continual power struggle between the civilian administrators who wanted a political solution, and the military who were aching to shoot and kill the enemy. ${ }^{39}$ 
However, by the middle of 1947, the Dutch military had won the power struggle with the civilian administrators. They decided that the time had come to throw down the gauntlet and force a military decision. ${ }^{40}$

\section{The first 'police action'}

For political reasons, the first large-scale operation planned for July 1947 (plus a second one in 1948-1949) was called 'police action'. In reality, it was to be a conventional mobile warfare campaign with the military strategic objective of physically occupying most key Republican-held territories on Java and Sumatra and breaking the Republican back in order to force them to make concessions at the negotiation table. The three army divisions on Java, supported by ten air force squadrons, four navy destroyers and seven landing craft, would break out from the Dutch-held enclaves of Batavia and Surabaya, while the marine brigade effected beach landings on the far eastern end of Java. These columns, mostly motorised infantry supported by artillery, light Stuart and medium Sherman tanks and light B-25 bombers, would conduct fast advances to take the greater part of Java and Sumatra (Operation Product). In a second phase, the occupied areas would be 'pacified' (Operation Rotterdam). One division would operate on Sumatra. ${ }^{41}$

It would take us too long to describe this first 'police action' in detail. Suffice it to say that it achieved tremendous operational and tactical success, but it had to be terminated after two weeks (20 July to 4 August 1947) because of unbearable international pressure on the Dutch government from the United Nations and especially America. The soldiers were utterly disgusted, but they had to obey orders and stop. In particular, they were angry that they were not allowed to take Yogyakarta, the Republican capital, thereby allowing the Republican government to survive.

Based on the descriptions provided by Dutch military and civilian historians and journalists, ${ }^{42}$ we may, however, make a few relevant general observations.

On the level of conventional mobile warfare, the operation was professionally conducted by a relatively competent army, which had developed far from the blundering incompetence with which the German and Japanese invasions were met in May 1940 and February 1942. This was in spite of insufficient weaponry, logistics and experience of most formations. When the operation ended, albeit prematurely, Dutch territorial control was extended to two thirds of Java. Most of the economically important plantations, coal mines and oilfields were taken. At the same time, there were not enough troops to replicate the Java success on Sumatra, where the territorial extension was more modest. ${ }^{43}$

The firepower of the Dutch attacking forces was overwhelming. They often planned for (and achieved) tactical surprise and, where necessary, by-passed Republican strongpoints in order to keep up the blistering pace of the advance. Speed was expressly calculated as an important factor in their success, as it kept the Republicans on the back foot and forced them to react, preventing them to regain the 
initiative. The Dutch succeeded in getting inside the nationalists' decision loop: by the time the Indonesian leadership would decide on a response to a certain situation, that situation would already have developed so much further that their decision was irrelevant. (This reminds one of similar lightning advances by the Germans in France in 1940, and in Russia in 1941, as well as those by the Israelis in the Sinai in 1967, and the Americans in Iraq in 2003 - all with similar tactical results). What made this pace even more remarkable was the very difficult terrain, consisting of jungles, mountains and rivers.

On the other side, the Republican units were neither trained nor equipped or organised to stop such an offensive. The most they could do, was to try to slow down the Dutch advance by destroying bridges - and even there they were sometimes surprised and prevented from carrying out their sabotage actions - and mining roads.

The operation resulted in renewed negotiations and in January 1948 in the socalled 'Renville Agreement' (so named because it was signed on an American naval transport, USS Renville) between the warring parties. The agreement in theory froze the situation as it was at the end of the operation. The front lines, known as the 'Van Mook Line' became the borders between Dutch-controlled and Republican territories. It also stipulated a ceasefire and the withdrawal of the estimated 30000 Republican fighters from behind the front. ${ }^{44}$ In addition, several hundred Dutch hostages, still in the same concentration camps where the Japanese had interned them, were freed. ${ }^{45}$

Thus, the tactical and operational success was impressive. However, this was not translated into either military strategic or security strategic level -

- Firstly, because of the international intervention, the operation was terminated before it could be completed. This gave the Republican government and forces a breathing space, which they, as we shall see, grabbed with both hands.

- Secondly, the strategic thinking driving the operation was too orthodox, too much influenced by a typical WWII approach. The expectation was that occupying enemy territory - as was the case in the last years of that war - would mean the defeat of the opponent. However, although this 'police action' (and the second, police action still to be analysed) extended the territory under Dutch control to a great extent, this did not mean victory. This was not a conventional war, in spite of the conventional nature of the police action(s). Rather, the fundamental nature of the conflict was that of an insurgency war by the Republicans.

- Thirdly, General Spoor wanted to push further and take the Republican capital of Yogyakarta, but the government in The Hague was unwilling to defy the UN openly and forbade him to do it. Nevertheless, Spoor kept a considerable part of his forces in reserve for an advance on Yogyakarta, which created a gap for the insurgents to start a guerrilla war in the regions out of which they had just been driven. ${ }^{46}$ 
- Lastly, the Dutch occupying swathes of Republican territory proved to be like the dog that had caught the bus - what to do with it. The fact is that the Dutch never planned for an efficient civilian administration of these territories. They did not really envisage the period after the operation. ${ }^{47}$

\section{Counter-insurgency}

We will have to digress here a little. One of the primary strategical thinkers of the $20^{\text {th }}$ century, French General André Beaufre - he saw action during the Algerian War of Freedom (1954-1962), also an insurgency - wrote:

For guerrilla warfare, it is a question of menacing the adversary over the largest possible area... Doing so, it obliges regular forces to disperse their means over an area exceeding their capability, while the guerrillas remain capable of acting wherever they choose. ${ }^{48}$

In other words, by extending the disputed area, the insurgents forced their adversaries to overextend themselves. That means that the capability of the counterinsurgents to occupy and control an area was diminished, as they simply did not have enough troops to hold the disputed area in their grip. On the other hand, the insurgents had the freedom to roam around and decide where and when to attack - an outpost here, a patrol there, mining the roads, et cetera.

The irony is that the first 'police action' in a sense did the nationalists' work for them. The 90 000-odd uniformed men the Dutch had in the theatre at that stage were not nearly enough to impress their authority visibly on the areas they had 'conquered'. The fact that the Indonesians were not able to stop the lightning Dutch advances, actually played into the Indonesians hands. They fell back rapidly before the overwhelming Dutch firepower and thus conserved their own forces. In the relative chaos caused by the Dutch operation, many of their fighters stayed behind or slipped back to where they had come from, and thus created a force in being, able to be activated when the time came.

The Renville Accord had the same fatal weakness as its predecessor - nobody was really committed to it. Very soon, bands of Republican insurgents infiltrated over the Van Mook Line and started a guerrilla campaign. At the end of October, Governor-General Van Mook reported to The Hague that the nationalists had violated the ceasefire no fewer than 2570 times. ${ }^{49}$ According to Dutch military historian PMH Groen, an estimated 200000 guerrillas (that is, the greater part of the nationalist force) roamed the regions behind the Van Mook Line. The fact that the nationalists had an unoccupied part of Java and Sumatra, where their fighters could rest and recuperate, re-equip, reorganise and train furthermore played a definite role in sustaining the insurgents on the Dutch side of the Van Mook Line. ${ }^{50}$ 
To make things worse, Dutch military intelligence warned of increasing communist influence in the Republican camp - something that was worrying to the authorities against the background of an escalating Cold War. ${ }^{51}$ However, in September 1947, a communist revolt broke out against the nationalist Republican government in the city of Madiun, which had to be suppressed with considerable force and bloodshed. This had an important international consequence in that the nationalist Republicans were henceforth viewed as a credible anti-communist force in Washington. ${ }^{52}$ This would isolate the Dutch government at a crucial moment.

In the meantime, the Dutch did not have enough troops to control all the territory they had occupied effectively. Roads leading to isolated outposts were continually mined, so that some posts could only be supplied by air. Bridges were blown up, repaired and blown up again. The guerrillas evaded the Dutch troops, unless they were sure of success. The population furnished the insurgents with food, a place to hide, and - crucially - intelligence. A Dutch official, L. T. Vervloet, who made an inspection journey through the occupied regions in September 1947, reported that the enemy radio, broadcasting from Yogyakarta, had more influence on the locals than "our tanks". He described the pacification attempts as "a rough game of poker". ${ }^{53}$

In an attempt to cover all the ground, Dutch infantry patrols were split up into smaller units. Therefore, they even started losing some firefights. The Dutch counterinsurgency campaign, Rémy Limpach writes, "did not get further than countering symptoms and small local successes". ${ }^{54}$ Larger sweeps were subsequently thought to be the answer, but this simply meant that the country elsewhere was denuded of troops. This resulted in the Indonesians slipping back into the areas vacated by the troops and hiding in the mountains, jungles and among the locals in the villages and towns. ${ }^{55}$ The insurgents also concentrated on attacking the more or less isolated colonial plantations, partly because they were 'soft' targets and a symbol of the colonial injustice, and partly to disrupt the colonial economy and increase the price of not pulling out of Indonesia. For instance, by the end of 1947, 23 of the 28 plantations around Purwakarta in West Java had been abandoned. The hard-pressed military had to take on police duties as well. ${ }^{56}$

As military historian Jaap de Moor writes, “[a]fter 1945 it was about a large-scale people's war, to which the army could not find an adequate answer." 57

\section{'Hearts and minds' - the theory}

General Spoor initially expected that the simple Indonesian folk would support the renewed colonial occupation, as long as the Dutch military could guarantee their safety. If only they could rid the areas under their control of nationalist fighters, the locals would welcome their colonial overlords back - or so the Dutch leadership thought. (This approach had worked to some extent in previous centuries, and the natural assumption was that it would work again. $)^{58}$ Indeed, there are reports of villagers cheering and applauding the advancing Dutch columns during the first police action. What the victorious troops did not realise, was that these same villagers had 
also cheered and applauded the nationalists when these occupied the greater part of the country in the vacuum caused by the end of the war. As usual, the locals were the grass on which the elephants trampled when fighting; they were not actually on the side of the colonial forces. ${ }^{59}$

All modern theoretical analyses of insurgency or counter-insurgency warfare emphasise that the centre of gravity is not the armed forces of the enemy, but the hearts and minds of the local population. It is all very well to kill - say - 100 armed insurgents, but if that results in 500 new recruits for the rebels, the counter-insurgency has slipped backwards.

In the 1930s, Mao Zedong coined a slogan, which has since become the bedrock of counter-insurgency theory. Just as fish cannot survive without water, he wrote, the insurgents cannot survive without the support of the local people. ${ }^{60}$ Building on this, John A Nagl, one of the greatest theorists on counter-insurgency warfare, writes:

The indirect approach of defeating an insurgency by focusing on dividing the people from the insurgents, removing the support that they require to challenge the government effectively, is rather different from the direct approach and in the long term is usually more effective. Once the local and regular armed units are cut off from their sources of supply, personnel, and, most importantly, intelligence, they wither on the vine or are easily coerced to surrender or destroyed by the security forces with the aid of the local populace. Winning that support is the critical battle in a counterinsurgency campaign ... ${ }^{61}$

The man responsible for the slogan "winning hearts and minds" ${ }^{2}$ was the British General Sir Gerald Templer, who directed the anti-communist counter-insurgency campaign in Malaya in the 1950s. With the concurrence of the British government in London, Templer realised two things: first, that Malaya was to become independent, irrespective of how the British felt about it. By recognising this, the wind would be taken from the insurgents' sails. The second was that the communist insurgency could only be defeated with the help of the Malayan people themselves. ${ }^{63}$ As he put it, "[t]he answer lies not in pouring more troops into the jungle, but in the hearts and minds of the people." ${ }^{\prime 4}$ It mostly worked, and the communist insurgency was defeated.

In addition, a French officer on secondment to the American army in the sixties, David Galula, wrote a short study on counter-insurgency warfare, in which he correctly opined that such a war consisted of no more than $20 \%$ military means, while $80 \%$ was political - which included social and economic policy. ${ }^{65}$ 


\section{'Hearts and minds' - the practice}

Of course, Templer's insights came only some years after the Indonesian conflict. But the contrast with the Dutch approach could not have been greater. The Dutch, who had witnessed the brutal (and mostly ineffective) way in which the Germans had clamped down on organised resistance all over Europe, ${ }^{66}$ chose to repeat their own brutal strategy dating from the era when they originally subjugated Indonesia. As Dutch sociologist Jacques van Doorn observed, while the Dutch were building an exemplary democracy in the Netherlands, at the other end of the world, they practised "a centralistic organised autocracy which finally resembled a police state". ${ }^{67}$ To make matters worse, the Dutch government refused to use the word 'war' when referring to the conflict (which is why they called the conventional operations of 1947 and 1948-1949 'police actions'). This meant that, as far as the Dutch were concerned, the laws of war did not apply to their military actions in the East Indies. ${ }^{68}$

Van Doorn, who himself fought in the war as a conscript, later summarised the Dutch approach:

'Cleansing' was the key concept, and it applied to the top as well as the base. The Republican government had to be cleansed of 'irresponsible elements' before political business could be done with the Netherlands. The villages had to be cleansed of 'terrorists' and 'gangs' so that the population could at last enjoy peace and prosperity again. With the skimming off of the foam on top all problems would be solved, for the Dutch authorities and for the indigenous population. ${ }^{69}$

The fact is, however, that the ordinary Dutch troops had no sympathy for the Indonesian cause, nor did they understand anything about the Indonesian people and culture. $^{70}$

A necessary nuance to be made clear here is that some indigenous groups - for example, the ethnically distinct Sundanese in West Java - actively supported the Dutch war effort, as they feared that the majority of Javanese would ride roughshod over them. ${ }^{71}$ This, of course, does not alter the main narrative.

Dutch questionable actions started right from the beginning, even before the British had left. Many officers and men handled the locals, who were suspected of harbouring nationalists, harshly. In the southern part of Celebes, a certain Captain Raymond Westerling, an ex-member of the KNIL, recruited his own band of Ambonese ex-soldiers, augmented them with Dutch special forces and parachutists, and started a cruel campaign to clear the southern part of Celebes of nationalists. Even at this early stage of the war, an estimated 3000 Indonesians - many of them civilians - were murdered. The British and Dutch military leadership did not exactly like it, but did nothing to stop it. ${ }^{72}$ (In 2012, photographs of one such mass murder, where Indonesians were executed, turned up in a Dutch newspaper. Apparently, these 
came from the private album of a Dutch soldier and were fished out of a rubbish container. ${ }^{73}$ )

Vengeful colonials, eager to take revenge for the Bersiap terror, also ran amok for a while amongst the locals in the territories controlled by the Dutch. A British officer spoke of a "sort of unofficial Gestapo headquarters" in Batavia, where suspects were interrogated, assaulted and sometimes tortured. ${ }^{74}$ It is logical to assume that this did not exactly endear the Dutch to the Indonesian population.

Part of the problem, according to Van Doorn, was that the naïve Dutch conscripts, arriving by ship from the far-off Netherlands, had absolutely no idea of the Indonesian situation. They believed all the propaganda that the enemy were dastardly terrorists, and that they had to restore law and order. Furthermore, the ex-KNIL soldiers, hardened by war, Japanese captivity and the excessive bloodshed of the nationalists in the Bersiap period, were responsible for introducing the newcomers to war in Indonesia - and these did not believe in molly-coddling the locals. ${ }^{75}$

Several academics who examined the Dutch practice when dealing with the Indonesian civilian population have stated that war crimes were not, as previously thought, incidentally and periodically perpetrated. On the contrary, they were systematic and part of the military policy. In 2015, a team of researchers published a selection of veterans' reminiscences. They went through 100000 pages of text from 659 accounts by 1362 Dutch eyewitnesses, less than $1 \%$ of those involved in the conflict. Yet, even on this very limited basis, at least 779 acts that could be classified as war crimes were uncovered. The conclusion was that "the total number of crimes is more likely to amount to tens of thousands than thousands". ${ }^{76}$

As Rémy Limpach concludes after an exhaustive analysis of several hundred pages:

Regarding the extreme Dutch violence it very clearly did not apply to isolated incidental cases or regrettable exceptions. Dutch military were structurally guilty of mass violence and certain units even did it systematically. This means that excessive violence was part of a strategy a system, such as by the [Westerling] commandos in South Celebes and the systematically torturing intelligence services. From the top this systematic utilisation of violence was condoned openly or connived at. ${ }^{77}$

Several mass murders have been investigated in great detail. Here, we consider only one, which caused a great deal of agonising when it was exposed in 2008 the killing of all (or nearly all) the men of the West Javanese village of Rawagade (also written Rawagadeh). In that year, the surviving elderly widows of some of the murdered men took the Dutch government to court for compensation. In 2011, the judges at last ruled in their favour. ${ }^{78}$ 
What happened on that fateful day in December 1947 was that the village of Rawagade in West Java had the misfortune of being in the path of a Dutch infantry company of 80-90 men, who were looking for the local guerrilla leader. Apparently, the man had been in the village, but had left the previous day - which the patrol, of course, did not know. When the soldiers could not find him, they rounded up the male villagers and started shooting them indiscriminately. They did not stop until all the men they could lay their hands on - according to different sources, 312, 431 or 433 of them - lay lifeless on the ground. What makes this even more shocking was that the murders were committed by ordinary conscripts in the regular army under the command of a professional officer. The major in command of the patrol was afterwards ordered to remain silent about the murders. The matter was swept under the carpet. $^{79}$

This was not the only such war crime; it is merely the most well-known example. Researchers have also uncovered several other mass murders, mostly - but not always - committed by KNIL soldiers or special forces. ${ }^{80}$ Jacques van Doorn, himself an eyewitness, later wrote that it was untrue that the ordinary Dutch soldiers did not know of excessive violence:

They often heard about it, sometimes they stood by or even participated. But they saw it differently: They were involved in the 'dirty war' intrinsic to counter-guerrilla operations, and they saw the excesses therefore mostly as unavoidable, at the most regrettable collateral consequences. ${ }^{81}$

In addition, an examination of the air operations shows that the need to limit civilian casualties was a low priority with the Dutch Air Force. ${ }^{82}$

Interestingly, a comparison of Dutch and Indonesian archival sources shows that the Dutch military in their official reports did not consciously differentiate between enemy fighters and civilians (granted, in any insurgency a notoriously difficult matter). To the writers of these reports, all those killed on the Indonesian side were automatically insurgents. The Indonesian reports of the same battles, on the other hand, regularly refer to "civilian casualties". ${ }^{83}$ The truth will probably be somewhere in the middle. Nevertheless, clearly enough, civilians were killed in order to galvanise Indonesian resistance.

What it boils down to on military strategic level, is explained by military historian Jaap de Moor:

It is clear that the Netherlands indeed followed a consistent approach in its colonies and that this was absolutely military in nature. For hearts and minds or tache d'huile [oil spot approach], there was no place ... The many shapes which resistance and uprising took on were consistently taken on by a military approach. In addition, civil authority often was in the hands of the military. ${ }^{84}$ 
Attempts to coordinate the military strategy and civilian policy better came to naught. ${ }^{85}$

Right at the end of the war, in March 1949, a Dutch battalion commander, Lieutenant Colonel FOB Musch, came to the discovery that the insurgency could not be beaten just by military means, but that politics had to play a role as well. In a memorandum, he expressed sharp criticism of the Dutch strategy:

The more wavering our political course is, the more mercilessly our troops have to conduct themselves. One cannot escape this interaction. The situation at this moment is already thus far, that in some areas one can speak of a contraterror. $^{86}$

It seems that the Dutch had learnt nothing from their own experience on the receiving end from the Germans during WWII. Rather, their historic example was their colonial warfare experience, which, at best, was a rather brutal affair.

Of course, one should not shut one's eyes to the other side of the coin. The nationalists did not shrink back from intimidating or killing anyone suspected of collaborating with the Dutch. Late in 1947 (halfway through the war), the Dutch estimated that 3500 people had been murdered thus, a number that one researcher calls "probably too low", 87

\section{The second 'police action'}

During the course of 1948, it became clear that the apparent operational and tactical success of the first 'police action' disguised its utter strategic failure. The violent attacks on civil administrators, village elders, and plantation personnel grew ever more in number and more vicious in nature. The number of serious incidents rose from 90 in March 1948 to no fewer than 160 in both May and June, peaking at 250 in August. General Spoor's efforts to 'indigenise' the army in order to make more use of native troops' better local knowledge did not get very far. ${ }^{88}$

Historian Roel Frakking, who examined the guerrilla war in Central Java in great detail, describes the situation in the last months of 1948:

Dutch security forces and the Indonesians fighting with them did very little to ameliorate the situation or improve the population's trust in the security forces. Harsh, draconian measures, such as extra-judicial killings and village burnings, became part and parcel of standard military patrols, punitive measures, and intelligence-gathering. ... [T]he Indonesian people as a whole was thus caught between a rock and a hard place. Republican forces stepped up the violence against what they perceived to be Indonesian collaborators. 'Shadow' administrations injected themselves into villages, 
displacing those who may still have answered to the Inland Administration. Kidnappings and murders of village elders were common. Every day, European planters complained: 'Indonesian government officials and employees, working on the plantations, are murdered in horrible ways and their mutilated bodies put on display.' The planter community itself, the bulwark of Dutch colonialism and its predatory capitalism, restlessly peered into the abyss from where the utter abandonment of the plantations stared back menacingly. Military commanders reported about deserting police and paramilitary units with ever-increasing frequency. The 'desertion evil' was so pervasive that it slowly started to affect the Royal Land Forces and those Indonesians in the Royal Netherlands-Indisch Army. ${ }^{89}$

In view of the worsening security situation, the Dutch authorities decided that it was high time to finish the job at last by occupying the remaining nationalist territory on Java and the greater part of Sumatra, to occupy the Republican centres of Yogyakarta and Fort De Kock (the latter on Sumatra), and to eliminate the Republican government altogether (Operation Kraai, or 'Crow'). This would be done with the same fast advances that worked so well during the first 'police action', with motorised infantry, supported by artillery, light and medium tanks and light bombers. Altogether 102000 men were available for the operation on Java, and another 22500 on Sumatra. ${ }^{90}$

The military strategic objective of the operation, according to General Spoor, was to "destroy the power of the present [Indonesian] republic. This therefore implies that the first operational objective can be just its central point, at the same time the symbol of the Republic: Yogyakarta." $" 1$

The timing could not have been better. The Indonesian forces were still in considerable disarray because of the civil war-like conflict between the nationalists and the communists in Madiun shortly before. To restore the nationalist war-fighting capacity, their commander, General AH Nasution, ordered a series of large-scale exercises and manoeuvres on West Java, starting on 19 December 1948 (coincidentally the same day as the start of the Dutch operation). That meant that the explosives under several bridges leading to Yogyakarta and under the runaway at the airfield were disconnected and that the nationalist army was badly placed to ward off the offensive. ${ }^{92}$

The second 'police action' therefore started with a spectacular thunderclap, a daring air assault on Yogyakarta. Two companies of Special Forces were parachuted onto the airfield outside the city early in the morning and captured the airfield easily, completely surprising the bewildered defenders. This made it possible to rapidly fly in two infantry battalions and the rest of the Special Forces battalion. This was followed by a quick Dutch advance to take the city, denuded of defenders by 
Nasution's exercises. The city was taken before nightfall. The nationalist movement was decapitated, or so the elated Dutch thought. ${ }^{93}$

A detailed description of this operation will not be necessary. ${ }^{94}$ Suffice it to say that it replicated the approach and tactical/operational success of the first police action to a large extent. Once again, the Dutch columns advanced like lightning, once again they achieved great operational and tactical surprise, once again the regular Dutch army acted with great professionalism. That is, if one views the operation as an orthodox mobile conventional operation - which it was, of course, only partly. The character of the war as such was not that of a conventional mobile conflict, however well the army fared at this level. It was essentially an insurgency war, and therefore it has to be analysed as such.

What did the second 'police action' achieve? Most Republican government members (including President Sukarno and Vice-President Hatta), surprised by the lightning air assault on Yogyakarta, were captured. The three army divisions on Java broke out of Dutch-held territory and advanced rapidly, rolling over the feeble resistance with relative ease. The marine brigade stormed the north-western beaches and moved inland. These forces met each other after a few days, consolidating their progress. On Sumatra, considerable pieces of territory, especially the important oilfields, were occupied as well. By the end of the operation, on 5 January, the whole of Java and a large part of Sumatra were in Dutch hands. General Spoor said he was "reasonably satisfied" with the results. ${ }^{95}$

However, Dutch military historian J Hoffenaar correctly calls this a "Pyrrhus victory" ${ }^{96}$ In spite of the territorial conquest and the impressive tactical and operational success, it was a strategic disaster and a political blunder. To begin with, the operation showed exactly how isolated the Netherlands were. The Indonesian governments of East Indonesia and West Java - hitherto viewed as Uncle Toms by the nationalists resigned in protest. The United Nations Security Council rapidly approved a resolution calling on the Netherlands to call off the operation to free the Republican government leaders and to pull back from Yogyakarta. America discreetly let it be known that it would reconsider its Marshall Plan Aid to the bankrupt Netherlands. This would have been a catastrophe. Therefore, seeing that the main operational objectives had been reached, the operation was halted on 5 January $1949 .{ }^{97}$

Secondly, the operation did not succeed in the objective of breaking the back of the enemy. Although most of the government members were taken prisoner, enough of them escaped to continue providing political leadership to the struggle. The day Yogyakarta was taken by the Dutch, the Republican government decided in its last, hastily convened meeting to revert to a full-scale insurgency war. Orders went out to the army to evade the Dutch conventional juggernaut and to begin guerrilla operations behind the lines. This meant that the Republican war effort was not crushed, as the Dutch high command had hoped. ${ }^{98}$ 
In fact, in January and February 1949, General Nasution issued detailed orders for the organisation of the Republican guerrilla war against the colonial power. He also made sure that a "non-cooperation" order went out: All Indonesian local officials were forbidden on pain of punishment as traitors to collaborate with the Dutch. The idea was a "total guerrilla war" whereby the insurgents concentrated on Dutch communication lines, convoys, supplies, as well as collaborators and police officials. ${ }^{99}$ To demonstrate that they had not been beaten, an Indonesian force of 2000 men occupied Yogyakarta for a few hours on 1 March 1949. This was intended as a show of force. ${ }^{100}$ Thijs Brocades Zaalberg describes how things developed from here:

Meanwhile, the Republican shadow governments, that had been successful in the previous year, came to full effect in that final phase. While continuing to take massive casualties in the military domain, the Republic effectively won the battle for control of the population in the governance sphere. Having undermined Dutch authority and the federal structure for two years, it took little effort to tear it down once the colonial power had overstretched itself dramatically while simultaneously squandering vital international support. ${ }^{101}$

As the Renville Agreement unravelled, the TNI stepped up its insurgency. Violence flared up dramatically, and soon the Dutch army discovered that it was hopelessly overstretched. Already after the first police action, the nationalists had created parallel civilian control mechanisms in the villages, where they, not the Dutch, were the real authority. ${ }^{102}$ As Henry Kissinger wisely wrote in 1969, "[w] hereas the guerrilla wins if he does not lose, the conventional army loses if he does not win." 103

In fact, by early 1949 , the Republic had captured the military initiative. ${ }^{104} \mathrm{By}$ May, the Dutch possessed the cities, but the Republicans were masters in the rural areas. ${ }^{105}$ The second police action was the high point of the Dutch war effort, but it was a false high point. Hereafter things started to go downhill - fast. Only a few weeks after the seeming success of the operation, the Dutch started to see the light. In May, under unbearable international pressure, they signed an agreement that would pave the way for a transfer of sovereignty. A formal ceasefire followed in August with the Dutch pulling back from Yogyakarta, and by December, Indonesia was a free country, largely on the Republicans' own terms.

\section{Conclusion}

The Indonesians thus won the war hands down. In the end, Indonesia became an independent country mainly according to the demands the nationalists put in the first place. The Dutch came away humiliated and cowed. In the years that followed, the war was barely mentioned. Only in recent years, a desultory attempt has come off the ground to confront not only the loss of the war, but the war crimes committed by a country, which has come to think of itself as a moral beacon, able to preach to the world about human rights. 
In order to understand why the Dutch lost, we will have to answer some related questions.

Firstly, what was the nature of the war? Contemporary Dutch military writings show that their military did not really understand the nature of the conflict. One does see references to "guerrilla war", ${ }^{106}$ but no consciousness that this was a true 'people's war', where the population formed the centre of gravity in the sense that Von Clausewitz meant the term. Therefore, the Dutch command laboured under the misconception that the insurgency by the nationalists could effectively be countered with orthodox conventional mobile warfare, as testified to by the two 'police actions'. Although these operations, as measured against conventional war conditions, were conducted intelligently and professionally, they were exactly the wrong answer.

At the same time, the Dutch never understood that military means were not nearly enough. Not only did they neglect the civilian administration of the occupied territories, but they also actively maltreated, tortured, raped and murdered their way through them. Whereas the Germans (without excusing what they did) at least did not wipe out entire Dutch villages during WWII, the Dutch - even ordinary conscripts - at times did so with abandon. The little chance they had of winning over the locals was thereby squandered. In fact, as far as they had a counter-insurgency doctrine, it was literally the stuff of comic books. They had a manual, Voorschrift voor de PolitiekPolitioneele Taak van het Leger (Manual for the Political-Military Task of the Army), but Jaap de Moor says it was little more than a collection of tips about encircling villages and houses and about patrolling. It merely paid lip service to minimising the use of violence and to civil-military cooperation. It was presented in comic-book form to the troops. It was revised after 1945, but was used primarily to warn inexperienced Dutch conscripts of the dangers of warfare in tropical terrain against guerrillas. As Zaalberg writes, "[t]his would hardly prepare commanders for a fullspectrum, popular insurgency." 107

Secondly, how realistic was the Dutch strategic objective? When the Dutch started coming back to the Dutch East Indies in the course of 1946, their instinctive idea was to return the territory to the status quo antebellum - that is, to restore Dutch rule fully. Under enormous international pressure, however, they created an elaborate federal structure, which, however, was essentially a smokescreen for continued colonial domination. Coert DuBois, the American State Department's chief mediator in the Indies in 1948, called the proposed federal state structure an unnatural organisation, which could be maintained only by Dutch arms. ${ }^{108}$

The Dutch did not realise that the post-war political situation had changed so dramatically that this was a pipe-dream to start with. Their closest ally, Britain, had ambivalent feelings about the Dutch in Indonesia, as they themselves were pulling out of their own jewel in the crown, British India. The Americans were vehemently against the restoration of any colonial authority and repeatedly came down hard on the Netherlands. As America was the main benefactor to the Dutch in terms of Marshall Plan Aid and as military shield against the Soviet Union, The Hague not only had 
to take Washington's feelings seriously; with the active opposition of the United States to their war effort, there was no way in which the Dutch could retain control in Indonesia.

In Indonesia itself, the Dutch humiliation of 1942 at the hands of an Asian power, Japan, had irrevocably smashed colonial moral authority. When the Dutch came back, most Indonesians were dead set against them. They might not have been terribly excited about the harsh treatment they experienced from their Republican countrymen, but at least these were their 'own', from whom they were prepared to endure far more hardship than from the Dutch 'others'.

The conclusion is clear. The Dutch strategic objective was totally unrealistic. There was no way they could have kept control of Indonesia. There was also no real attempt to win the hearts and minds of the locals. And, even if they tried, given the circumstances, the chances of success in this respect were almost nil. From that flowed most of their other mistakes as well.

A third question is how other European colonial powers fared in similar conflicts in more or less the same time. The French fought in two of their colonies, Vietnam and Algeria, and also heavily depended on military means, instead of Galula's $80 \%$ political approach. Their strategic objective, too, was to cling to the colonies. To a large extent, they approached the wars as conventional conflicts, and in both cases, were badly humiliated. ${ }^{109}$

The British experience was rather more nuanced. They clamped down harshly on the Kenyan insurgency and were in the end forced to give up the colony. ${ }^{110}$ On the other hand, partly through the intelligent approach of Sir Gerald Templer in Malaya, in a certain sense, the British won that conflict. They could not keep onto the colony, but handed over control to the locals on their own terms. The insurgents did not gain control. There the formula, to win over the 'hearts and minds' of the local population, was amply proved. ${ }^{111}$ (As an aside, the Americans also viewed 'their' war in Vietnam largely through conventional glasses. The 'hearts-and-minds' approach was perverted: "[i]f you've got 'em by the balls, their hearts and minds will follow" seemed to have been their adage. ${ }^{112}$ They too left Vietnam humiliated.)

The Indonesian War of Independence was very costly to both the Netherlands and Indonesia. The Dutch suffered an estimated 6000 dead. According to Adrian Vickers, somewhere between 45000 and 100000 Indonesian military and 25000 100000 Indonesian civilians were killed. Altogether 7 million people were internally displaced. ${ }^{113}$ The 130000 military, whom the Dutch had in the operational theatre by December 1948, was economically unsustainable for a country emaciated by a cruel five years of German occupation. The Dutch force was in fact slightly larger than the French force in Algeria at the end of the fifties (with a population far surpassing that of the Netherlands). ${ }^{114}$ 
In the SANDF, the expertise on counter-insurgency warfare, built up during the eighties, has sadly gone downhill. Hopefully, this article will go some way to rekindle the interest in this genre of warfare. Therefore, some final thoughts, which may be of relevance to the SANDF.

- Firstly, always remember that there is a fundamental difference between conventional warfare and counter-insurgency warfare. The first is about the intelligent application of maximum violence at the right place and at the right time; the second is about the optimum amount of violence, which would often be the minimum amount of violence. The insurgents' centre of gravity is not their army; it is the hearts and minds of the local population. Whoever wins this extremely complicated and difficult battle, will stand the best chance of winning a war. By maltreating the locals on a fairly massive scale, the Dutch contributed considerably to their own defeat.

- In the second place, do not set your sights on an unrealistic strategic objective. The Dutch wanted to preserve their domination in Indonesia, which was completely impossible in the international and Indonesian political climate after 1945. Even the British realised that they could not hold onto their empire after WWII, and they came away from India, Malaya and other colonies with considerable less loss of prestige.

- Thirdly, the Dutch war emphasises the need for unified civil-military decision-making. All too often the Dutch politicians and military each went their own way; all too often the soldiers succeeded in imposing their aggressive views on the politicians. In this way, the military also played an important part in their own humiliating defeat.

These are lessons the SANDF need to internalise thoroughly, should the South African military ever again become involved in a counter-insurgency war.

\section{Endnotes}

${ }^{1}$ Dr Leopold Scholtz is a retired political commentator, writing for several news media. He is also a military historian with many academic publications on his CV, and the writer of The SADF in the Border War 1966-1989 (Cape Town: Tafelberg, 2013) as well as The Battle of Cuito Cuanavale (Solihull: Helion, 2016) and Ratels on the Lomba: The story of Charlie Squadron (Johannesburg: Jonathan Ball, 2017). He is a research fellow at North-West University's Research Focus Area Social Transformation (Potchefstroom campus). He retired as a captain in the Reserve Force of the South African Army.

${ }^{2}$ Cf. M Eickhoff. "Weggestreept verleden? Nederlandse historici en het Rawagededebat". Groniek 194. 2012. 53-67.

${ }^{3}$ CB Zaalberg. "The civil and military dimensions of Dutch counter-insurgency on Java, 1947-1949”. British Journal for Military History 1/2. February 2015. 67. 
${ }^{4}$ P Romijn. "Learning 'on the job': Dutch war volunteers entering the Indonesian war of independence, 1945-46". Journal of Genocide Research 14/3-4. September-November 2012. 318.

${ }^{5}$ A van Liempt. "Het mysterie van de Politionele Acties.". Historisch Nieuwsblad 6. 2011.

${ }^{6}$ CA Fraser. "The strategy of the revolutionary". Unpublished study, 1969.

${ }^{7}$ Cf. L Scholtz. The SADF in the Border War 1966-1989. Cape Town: Tafelberg, 2013, chapters 3 and 9.

${ }^{8}$ DP Baker \& E Jordaan (eds). South Africa and contemporary counterinsurgency: Roots, practices, prospects. Cape Town: UCT Press, 2010. I contributed a chapter about the war in Afghanistan to the book.

${ }^{9}$ JA de Moor. "Afscheid van Indië? Counterinsurgency in Nederlands-Indië, 1816-1949”. Militaire Spectator 177/3. 2008. 136-140; M Blessing. "Wilhelmina preekt de revolutie". Historisch Nieuwsblad 10. 2013.

${ }^{10}$ De Moor op. cit., p. 140.

${ }^{11}$ Blessing op. cit.

${ }^{12}$ G Teitler. "De oorlog om Indië, 1941-1949: Clio en Ares in het Verre Oosten". Militaire Spectator 161/3. 1992. 104.

${ }^{13}$ A Doedens \& L Mulder. Slag in de Javazee 1941-1942: Oorlog tussen Nederland en Japan. Zutphen: Walburgpers, 2017, 191.

${ }^{14} \mathrm{R}$ Limpach. De brandende kampongs van Generaal Spoor. Amsterdam: Boom, 2017,31 .

${ }^{15}$ Romijn op. cit., p. 320.

${ }^{16}$ Zaalberg op. cit., p. 67.

${ }^{17}$ PMH Groen. Marsroutes en dwaalsporen: Het Nederlands militair-strategisch beleid in Indonesië 1945-1950. 's-Gravenhage: SDU, 1991, 30; H Wagner. "Hoe kwamen de Indonesische strijdkrachten in de jaren ' 40 aan hun wapens? Militaire Spectator 156/11. 1987. 488.

${ }^{18}$ Groen op. cit., p. 18.

${ }^{19}$ WH Frederick. "The killing of Dutch and Eurasians in Indonesia's national revolution (1945-49): A 'brief genocide' reconsidered'. Journal of Genocide Research 14/3-4. 2012. 369.

${ }^{20}$ P Heijboer. De politionele acties: De strijd om 'Indië' 1945/1949. Haarlem: Fibula-Van Dishoeck, 1979, 12-19; R Cribb. "The brief genocide of Eurasians in Indonesia, 1945/46", in DA Moses (ed), Empire, colony, genocide. New York, NY: Berghahn, 2009, 424-436.

${ }^{21}$ Heijboer op. cit., pp. 12-19; J. Hoffenaar. "De Indonesische kwestie (1945-1949): De Nederlandse militaire inbreng nader bekeken". Militaire Spectator 4. 1987. 173; Romijn op. cit., p. 327.

22 J Bank. "Rubber, rijk, religie: De koloniale trilogie in de Indonesische kwestie 1945-1949”. BMGN-Low Countries Historical Review 96. 1981. afl. 2. 230-260.

${ }^{23} \mathrm{~J}$ de Beus. "God dekoloniseert niet: Een kritiek op de Nederlandse geschiedschrijving over de neergang van Nederlands-Indië en Nederlands Suriname". BMGN 116. 2001. afl 3. 308. 
${ }^{24} \mathrm{H}$ Langeveld. De man die in de put sprong: Willem Schermerhorn. Amsterdam: Boom, 2014, 290; L Ashworth. "The 1945-1949 Dutch-Indonesian conflict: Lessons and perspectives in the study of insurgency". Conflict Quarterly Winter 1990. 38.

25 JAA van Doorn. Gevangen in de tijd: Over generaties en hun geschiedenis. Amsterdam: Boom, 2002, 28-29.

${ }^{26}$ Blessing op. cit.

${ }^{27}$ Limpach op. cit., p. 53.

${ }^{28} \mathrm{HW}$ van den Doel. Afscheid van Indië: De val van het Nederlands imperium in Azië. Amsterdam: Prometheus, 2001, 128-130.

${ }^{29}$ J. Hoffenaar. "De militaire aftocht uit Indonesië 1949-1951". Militaire Spectator 9. 1990.413.

${ }^{30} \mathrm{M}$ Ceulen. "De vuile oorlog: De politieke verantwoordelijkheid voor de oorlogsmisdaden in Nederlands-Indië 1945-1949”. MA thesis, University of Utrecht, 2016, 21.

${ }^{31}$ JA de Moor. Generaal Spoor: Triomf en tragiek van een legercommandant. Amsterdam: Boom, 2011, 179-180.

${ }^{32}$ Groen op. cit., pp. 17, 48-49; cf. also Romijn op. cit., p. 324.

${ }^{33}$ Groen op. cit., pp. 23-25, 77-78.

${ }^{34}$ J. Hoffenaar. "De militaire aftocht uit Indonesië 1949-1951". Militaire Spectator 9, 1990. 413.

${ }^{35}$ De Moor, “Afscheid van Indië? ...” op. cit., p. 141.

${ }^{36}$ Groen op. cit., p. 19; Heijboer op. cit., p. 26; Ceulen op. cit. p. 56; De Moor, Generaal Spoor ... op. cit., p. 224; "Officiële mededelingen van het Kon. Nederl. Indonesische Leger: Korpsgeschiedenis van het IVe bataljon infanterie van het K.N.I.L.”. Militaire Spectator. 9-13.

${ }^{37}$ Groen op. cit., p. 79; Heijboer op. cit., pp. 20-22.

${ }^{38}$ Ceulen op. cit., pp 57-58.

${ }^{39}$ Ibid., pp. 64-65.

${ }^{40}$ B Verhoeven. "Gemanipuleerde informatie? De rol van generaal Spoor in de inlichtingendienst de NEFIS ten tijde van de Indonesische onafhankelijksstrijd (1945-1949)". MA thesis, University of Utrecht, 2013, 63.

${ }^{41}$ Groen op. cit., pp. 81-82, 84-90.

${ }^{42}$ Ibid., pp. 100-109; Heijboer op. cit., pp. 32-84; F Snapper. "Guerrilla-achtige methoden". Militaire Spectator 10-95. 475-477; Hoffenaar, "De Indonesische kwestie ..." op. cit., pp. 173-174; CA Heshusius. "Het gebruik van tanks in Nederlandsch-Indië”. Militaire Spectator 1947. 109-117; “Officiële mededelingen van het Kon. Nederl. Indonesische Leger. Korpsgeschiedenis van het IVe bataljon infanterie van het K.N.I.L." (Militaire Spectator, 1947, pp. 9-13; WA Schouten \& HB Evers. "Het gebruik van de artillerie, ingedeeld bij de V-brigade gedurende en na de politionele actie". Militaire Spectator 1949. 225-235; WK Seyn. "Technische werkzaamheden uitgevoerd door het Korps Genietroepen van de B-divisie in West- en Midden-Java voor, tijdens en na de politionele 
actie 1947”. Militaire Spectator 1949335-349; AJ Cornelese. "De 1

Divisie ‘7 December' 35 jaar”. Militaire Spectator 1981. 387-397.

${ }^{43}$ Heijboer op. cit., pp. 86-91.

${ }^{44}$ Ashworth op. cit., p. 40.

${ }^{45} \mathrm{~L}$ de Jong. Het koninkrijk der Nederlanden in de Tweede Wereldoorlog, (Den Haag, NIOD, 1994), XII(2) p. 1144.

${ }^{46}$ Groen op. cit., pp. 105-109; De Moor, Generaal Spoor ... op. cit., pp. 277-288.

${ }^{47}$ Cf. Zaalberg op cit., p. 73.

${ }^{48}$ A Beaufre. Strategy for tomorrow. London: Crane, 1974, 39-40 (Beaufre's emphasis).

${ }^{49}$ De Moor, Generaal Spoor ... op. cit., p. 289.

${ }^{50}$ Groen op. cit., p. 117.

${ }^{51}$ Ceulen op. cit., pp. 60-63, 84-85.

${ }^{52} \mathrm{HJH}$ Alers. Om een groene of Rode Merdeka: 10 jaren binnenlandse politiek, Indonesië 1943-1953. Eindhoven: Vulkaan, 1956, 197; JECM van Oerle. "De weg naar Madiun: PKI en CPN tussen twee opstanden, 1927-1948". Politieke Opstellen 633-59, accessed on 1.3.2018, https://www.ru.nl/ publish/pages/660907/oerle-p.pdf.

${ }^{53}$ Limpach op. cit., p. 55.

${ }^{54}$ Ibid., p.55.

${ }^{55}$ Ibid., pp. 55-56; R Frakking. "“Who wants to cover everything, covers nothing': The organization of indigenous security forces in Indonesia, 1945-1950". Journal of Genocide Research, 14/3-4. September-November 2012. 340.

${ }^{56}$ Frakking op. cit., pp. 341-342.

${ }^{57}$ De Moor, “Afscheid van Indië? ...” op. cit., p. 141.

${ }^{58}$ Groen op. cit., p. 18; Ceulen op. cit., pp. 66-67; De Moor, “Afscheid van Indië? ..."op. cit., p. 141.

${ }^{59}$ Heijboer op. cit., p. 94.

${ }^{60} \mathrm{G}$ Fairbairn. Revolutionary guerrilla warfare: The countryside version. Middlesex: Penguin, 1974, 99.

${ }^{61}$ JA Nagl. Learning to eat soup with a knife: Counterinsurgency lessons from Malaya and Vietnam. Chicago, IL: University of Chicago Press, 2005, 28-29.

${ }^{62}$ Ibid., p. 91.

${ }^{63}$ Ibid., pp. 88-91.

${ }^{64}$ S Miller. "Malaya: The myth of hearts and minds". Small Wars Journal 2017. $<$ http://smallwarsjournal.com/jrnl/art/malaya-the-myth-of-hearts-andminds $>$ Accessed on 29 October 2017.

${ }^{65}$ D Galula. Counterinsurgency warfare: Theory and practice. New York, NY: Praeger, 2005, 90.

${ }^{66}$ Cf. M Bennett. "The German experience", in IFW Beckett (ed), The roots of counter-insurgency: Armies and guerrilla warfare, 1900-1945. London, Bladford, 1988, 60-82.

${ }^{67}$ J van Doorn. "De Indische les”. De Groene Amsterdammer. 18 January 2012.

${ }^{68}$ Ceulen op. cit., p. 66.

${ }^{69}$ Van Doorn op. cit., p. 29. 
${ }^{70}$ Romijn op. cit., p. 326.

${ }^{71}$ R Frakking. "'Gathered on the point of a bayonet': The Negara Pasundan and the colonial defence of Indonesia, 1946-1950". The International History Review 39/1. 2017. 30-47.

72 JA de Moor. Westerlings oorlog: Indonesië 1945-1950. Amsterdam: Balans, 1999, 128-159; Romijn op. cit., p. 331.

${ }^{73}$ L Nicolasen. "Eerste beeld van executies in Indië”. De Volkskrant. 10 July 2012.

${ }^{74}$ Limpach op. cit., pp. 184-187.

${ }^{75}$ Van Doorn op. cit., p. 33.

${ }^{76} \mathrm{G}$ Oostindie. Soldaat in Indonesië, 1945-1950: Getuigenissen van een oorlog aan de verkeerde kant van de geschiedenis. Amsterdam: Prometheus, 2015, 176.

77 Limpach op. cit., p. 738; $c f$. also JAA van Doorn \& WJ Hendrix. Ontsporing van geweld: Het Nederlands-Indonesisch conflict. Rotterdam: Walburg Pers, 1970, passim.

${ }^{78}$ Cf. M van Lieshout. "Weduwen Sulawesi schakelen rechter in". De Volkskrant. 28 December 2013.

${ }^{79}$ Limpach op. cit., pp. 323-328; J Boom. "Archiefmap 1304: Nieuw bewijs van massa-executie in Indonesië”. Groene Amsterdammer. 10 October 2008.; W Veraart. "Uitzondering of precedent? De historische dubbelzinnigheid van de Rawagade-uitspraak". Ars Aequi April 2012. 251-259.

${ }^{80}$ Cf. Romijn op. cit., pp. 328-331; B Luttikhuis \& CHC Harink. "Voorbij het koloniale perspectief: Indonesische bronnen en het onderzoek naar de oorlog in Indonesië, 1945-1949". BMGN 132/2. 2017. 52-53; B Luttikhuis \& AD Moses. "Mass violence and the end of the Dutch colonial empire in Indonesia". Journal of Genocide Research 14/3-4. SeptemberNovember 2012. 257-276; Ceulen op. cit., chapters 2 and 3.

${ }^{81}$ Van Doorn op. cit., p. 34.

82 J Lize. "De lucht boven de sawa's: Over de offensieve bijdrage van de luchtstrijdkrachten tijdens de dekolonisatieoorlog in Nederlands-Indië (1945-1950)". MA thesis, University of Utrecht, 2015, 35-36.

${ }^{83}$ Luttikhuis \& Harink op. cit., pp. 59-63, 67-71.

${ }^{84}$ De Moor, “Afscheid van Indië? ...” op. cit., p. 143.

${ }^{85}$ Frakking, "“Who wants to cover everything ..." op. cit., pp. 350-353.

${ }^{86}$ Groen op. cit., p. 213.

${ }^{87}$ Frakking, "“Who wants to cover everything ..." op. cit., p. 340.

${ }^{88}$ Ibid., pp. 343-347.

${ }^{89}$ Ibid., p. 347.

${ }^{90}$ Groen op. cit., pp. 140-144.

${ }^{91}$ Ibid., p. 147.

${ }^{92}$ Heijboer op. cit., p. 126.

${ }^{93}$ Ibid., pp. 126-127; JG de Beus (ed). Het laatste jaar van Nederlands-Indië:

Van de zwaarhouw der tweede politionele actie tot de handtekening onder de Souvereiniteitsoverdracht. Rotterdam: Ad. Donker, 1987, 43-50.

${ }^{94}$ Heijboer: Op. Cit.; Groen op. cit., pp. 171-195; JWM Schulten. "De tweede politionele actie: Politieke en militaire achtergronden”. Militaire Spectator 
12/167. 1998. 624-630.

${ }^{95}$ Heijboer: Op. cit, p. 146.

${ }^{96}$ Hoffenaar, "De Indonesische kwestie ..." op. cit., p. 174.

${ }^{97}$ Heijboer op. cit., p. 146; Groen op. cit., p. 221; Ashworth op. cit., p. 41.

${ }^{98}$ Heijboer op. cit., pp. 128-129; Groen op. cit., pp. 195-197; Verhoeven op. cit., p. 93.

${ }^{99}$ Groen op. cit., pp. 197-198.

${ }^{100}$ Verhoeven op. cit., p. 95.

${ }^{101}$ Zaalberg op. cit., pp. 81-82.

102 Ibid., pp. 72-73.

${ }^{103}$ Ibid., p. 69.

${ }^{104}$ Frakking, "“Gathered on the point ..." op cit., p. 35.

${ }^{105}$ Groen op. cit., p. 210.

${ }^{106} C f$. T van Strien, "De pioniers in Nederlandsch-Indië”. Militaire Spectator 1948. 607-613; Snapper op. cit., pp. 475-477; Groen op. cit., p. 213.

${ }^{107}$ Zaalberg op. cit., p. 73; JA de Moor. "Colonial warfare: Theory and practice. The

Dutch experience in Indonesia”. Journal of the Japan-Netherlands

Institute 2. 1990. 98-114.

${ }_{108}$ Van den Doel op. cit., p. 292.

${ }^{109}$ There is a vast body of literature about this. Examples are A Horne. A savage war of peace: Algeria 1954-1962. London: Macmillan, 1977; W Laqueur. Guerrilla: A historical and critical study. London: Weidenfeld \& Nicolson, 1977, 294-299, 262-269; Fairbairn op. cit., chapter 5; E de Durand. "France", in T Rid \& T Keaney (eds). Understanding counterinsurgency: Doctrine, operations, and challenges. London: Routledge, 2010, 17-22 and D Moran. Wars of national liberation. London: Cassell, 2002, chapters 5 and 8 .

${ }^{110}$ Two excellent studies about this conflict are C Elkins. Britain's Gulag: The brutal end of empire in Kenya. London: Jonathan Cape, 2005; and D Anderson. Histories of the hanged: Britain's dirty war in Kenya and the end of empire. London: Phoenix, 2005.

${ }^{111}$ Nagl op. cit., pp. 195-198.

112 This was, in fact, a quote by President Teddy Roosevelt, but Charles Wendell "Chuck Colson", chief council for President Richard Nixon, had the slogan on the wall in his office.

${ }^{113}$ A Vickers. A history of modern Indonesia. Cambridge: Cambridge University Press, 2005, 100.

${ }^{114}$ Zaalberg op. cit., p. 67. 